\title{
ION EXCHANGE TREATMENT
}

OF B PLANT PROCESS CONDENSATE

B. W. Mercer and J. G. Adams

November 1970

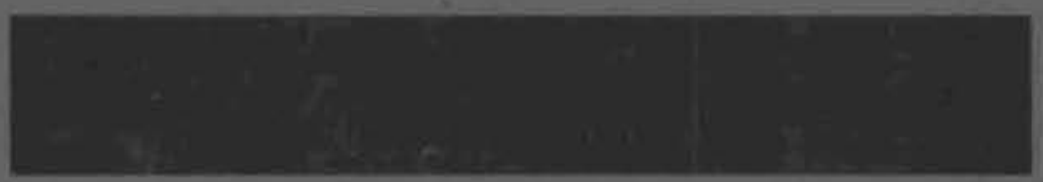

\section{AEC RESEARCH \& DEVELOPMENT REPORT}




\section{NOTICE}

This report was prepared as an cecount of work sponsared by the Unitod States Government. Neither the United States nor the Unitud Statos Atomic Ensergy Commistion, nor ony of their employees, nor any of their contractors, subsontractors, or their employees, mokes any worranty, express or implied, or astumes ony legol liability of responsibility for the accuracy, completeness ar usefulness of any informafion, opporatus, product or process disclossd, or represents that its use would not infringe privataly owned rights.

\section{PACIFIC NORTHWEST LABORATORY \\ RICHLANQ. WASHINGYON \\ operated by \\ BATTELLE MEMORIAL INSTITUTE}

for the

UNITED STATES ATOMIC ENERGY COMMISSION UNDER CONTRACT AT(45-1)-1830 


\title{
33679000617755
}

$$
\text { BNWL- } 1544
$$

UC-70, Waste

Disposal

and Processing

\author{
ION EXCHANGE TREATMENT \\ OF B PLANT PROCESS CONDENSATE \\ B. W. Mercer and J. G. Adams \\ Water and Land Resources Department \\ Environmental and Life Sciences Division
}

November 1970

BATTELLE MEMORIAL INSTITUTE

PACIFIC NORTHWEST LABORATORIES

RICHLAND, WASHINGTON 99352 
Printed in the United States of America Available from

National Technical Information Service National Bureau of Standards,

U.S. Department of Commerce

Springfield, Virginia 22151

Price: Printed Copy $\$ 3.00 ;$ Microfiche $\$ 0.65$ 


\section{ION EXCHANGE TREATMENT \\ OF B PLANT PROCESS CONDENSATE \\ B. W. Mercer and J. G. Adams}

\section{$\underline{\text { ABSTRACT }}$}

Laboratory experiments were conducted to evaluate ion exchange treatment of $B$ Plant process condensate. Ion exchange was found to be effective for removing the principal radionuclides providing the condensate was steam stripped to remove ammonia. The cation and anion exchange resins must be used in the $\mathrm{H}^{+}$and $\mathrm{OH}^{-}$form, respectively, for satisfactory removal of al1 radionuclides. The presence of $\mathrm{Ca}^{+2}$ and $\mathrm{Mg}^{+2}$ in the condensate limits the volume put through the ion exchange beds to ${ }^{137} \mathrm{Cs}$ breakthrough if the ammonia is reduced to near $0 \mathrm{mg} / 1 \mathrm{iter}$. 

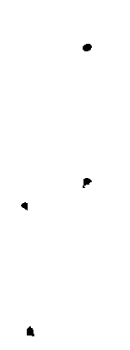
TABLE OF CONTENTS

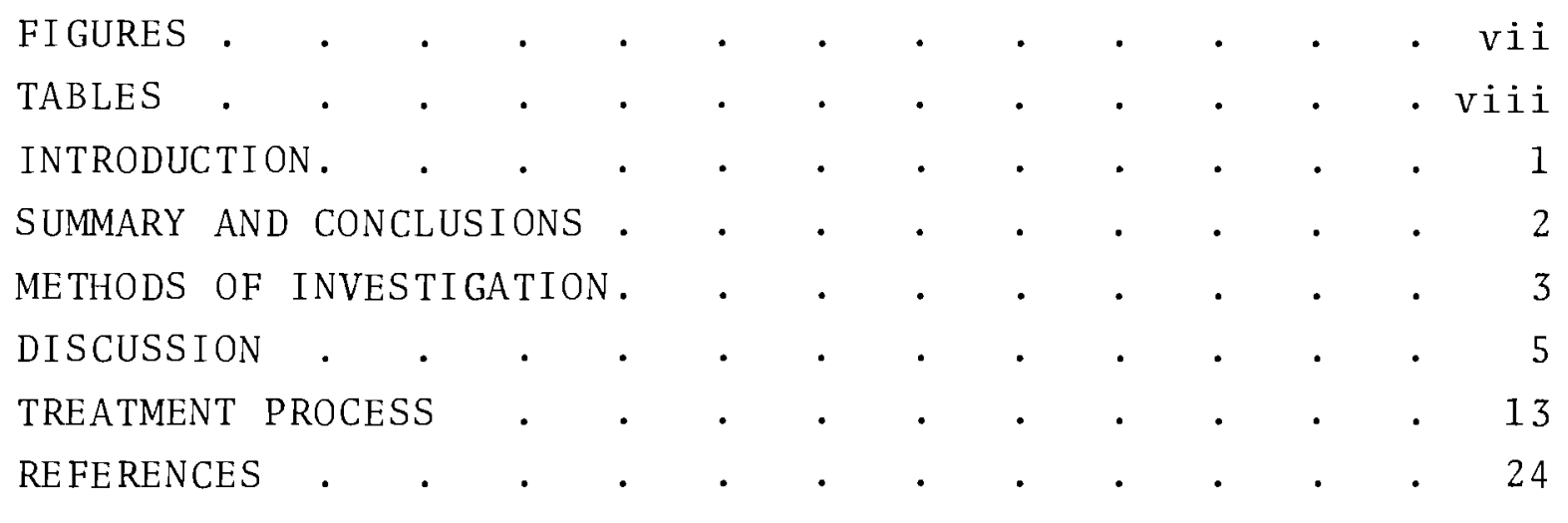




\section{FIGURES}

1 Breakthrough Curves for the Principal

Radionuclides in Steam Stripped BCP Put

Through Cation and Anion Exchange Columns

2 Breakthrough Curves for the Principal Radionuclides in Steam Stripped BCP Put Through a Cation Exchange Column in Water Recycle Run 1

3 Breakthrough Curves for the Principal Radionuclides in Steam Stripped BCP Put Through Cation and Anion Exchange Columns in Water Recycle Run 1

4 Breakthrough Curves for the Principal Radionuclides in Steam Stripped BCP Put Through a Cation Exchange Column in Water Recycle Run 2

Breakthrough Curves for the Principal Radionuclides in Steam Stripped BCP Put Through Cation and Anion Exchange Columns in Water Recycle Run 2

6 Breakthrough Curves for the Principal Radionuclides in Steam Stripped BCP Put Through a Cation Exchange Column in Water Recycle Run 3

7 Breakthrough Curves for the Principal Radionuclides in Steam Stripped BCP Put Through Cation and Anion Exchange Columns in Water Recycle Run 3

8 Elution Curves for Cesium and Strontium from the Cation Column Using 4M Nitric Acid Upflow

9 Elution Curves for Ruthenium and Antimony from the Anion Column Using $2 \mathrm{M}$ Sodium Hydroxide Upflow 


\section{TABLES}

1 Chemical and Radiochemical Analyses of BCP Samples

2 Removal of Ammonia, Organic Carbon, and Inorganic Carbon by Steam Stripping

3 Radionuclide Concentrations and Decontamination Factors for an $\mathrm{H}^{+}$Based Cation Resin in Series with an $\mathrm{OH}^{-}$Based Anion Resin Column with Steam Stripped BCP Sampled on 8/27/69

4 Radionuclide Concentrations and Decontamination Factors in Series for an $\mathrm{H}^{+}$Based Cation Resin and an $\mathrm{OH}^{-}$Based Anion Resin Column with Steam Stripped BCP Sampled on 9/15/69

5 Radionuclide Concentrations and Decontamination Factors for Effluents from $\mathrm{NH}_{4}^{+}$Based Cation Resin and $\mathrm{OH}^{-}$Based Resin Column in Series with Steam Stripped BCP Sampled on 9/15/69

6 Radionuclide Concentrations and Decontamination Factors for Effluents from $\mathrm{NH}_{4}^{+}$Based Cation Resin and $\mathrm{OH}^{-}$Based Anion Resin Columns in Series with Untreated BCP Sampled on 9/15/70 


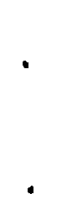

, . 


\section{ION EXCHANGE TREATMENT \\ OF \& PLANT PROCESS COHDENSATE \\ 3. A. Mercer and J. G. Adams}

\section{INTRODUCTION}

The low and intermediate level waste treatment program has the objective of providing economical methods for minimizing the release to the environs of radionuclides in liquid wastes. Emphasis is placed on the removal of radionuclides, particularly those with long half lives, by methods more economical than evaporation. One of the more attractive methods for the treatment of low and intermediate level wastes is ion exchange. (1) Under the proper conditions radioactive wastes may be decontaminated at a small fraction of the cost of evaporation. Removal efficiencies exceeding $99 \%$ are commonly demonstrated by ion exchange waste treatment processes and removal efficiencies exceeding $99.9 \%$ can be achieved in certain instances. (2)

Considerable research effort has been focused on the removal of ${ }^{137} \mathrm{Cs}$ from radioactive wastes $(3-5)$ using cesium selective zeolites. These zeolites are currently being used to remove ${ }^{137} \mathrm{Cs}$ and other radionuclides from low and intermediate level wastes at Hanford, (8) Savannah River, (1) and the National Reactor Testing Station. (9) Cesium selective zeolites are usually not effective for the removal of mixed fission products from wastewaters. These mixtures generally require total anion and cation removal (demineralization) to achieve high decontamination efficiencies. This is best accomplished under acidic conditions $(\mathrm{pH}, 2-4)$, although a strong acid cation resin in the $\mathrm{H}^{+}$form is often effective. The breakthrough of radioactivity from ion exchange beds is governed by the concentration of salts in the wastewaters which replace the $\mathrm{H}^{+}$and $\mathrm{OH}^{-}$of the cation and anion exchange beds. 
B Plant process condensate (BCP) has been characterized previously and found to consist largely of radioactive cesium, strontium, and cerium in essentially a dilute ammonia solution.

Measurable increase in concentrations of other fission products may be expected in the future. (7) In order to achieve discharge limits for all radionuclides, total demineralization by cation and anion exchange was deemed necessary. This report concerns a laboratory study of the decontamination of $B$ Plant process condensate by ion exchange.

\section{SUMMARY AND CONCLUSIONS}

1. Steam stripping and cation and anion exchange were found effective for reducing the concentration of total beta in B Plant process condensate (BCP) by one to two orders of magnitude. Cation exchange alone is effective for removal of ${ }^{137} \mathrm{Cs},{ }^{90} \mathrm{Sr}$, and ${ }^{144} \mathrm{Ce}-{ }^{144} \mathrm{Pr}$ from steam stripped $B C P$. Anion exchange is needed to reduce the levels of ${ }^{105} \mathrm{Ru}$ and ${ }^{125} \mathrm{Sb}$, although very little if any removal will be needed in most instances.

2. Ion exchange was not effective for the removal of the principal radionuclides witlout steam stripping. The concentration of ammonia is too high to attain adequate decontamination factors or volumes processed to breakthrough. The cation and anion exchange resins must be used in the $\mathrm{H}^{+}$and $\mathrm{OH}^{-}$form, respectively, for satisfactory removal of all radionuclides.

3. The presence of hardness $\left(\mathrm{Ca}^{+2}\right.$ and $\left.\mathrm{Mg}^{+2}\right)$ in the $\mathrm{BCP}$ appears to be the most likely limiting factor on volume throughput for the cation column to ${ }^{137} \mathrm{Cs}$ breakthrough if the ammonia is reduced to near $0 \mathrm{mg} / \mathrm{liter}$; however the ${ }^{137} \mathrm{Cs}$ breaks through the column ahead of the hardness.

4. Injection of a small amount of acid to the cation column feed will be necessary at times to assure a sufficiently low $\mathrm{pH}$ in the cation column for effective removal of ${ }^{90} \mathrm{Sr}$ and rare earth radionuclides. 


\section{METHODS OF INVESTIGATION}

Ion exchange columns were prepared by packing specified volumes of ion exchange resins in glass tubes with wire screens and/or glass wool at each end to hold the resins in place. Waste solutions were pumped downflow through the columns by means of peristaltic pumps. Regenerant solutions were pumped upflow through the resin columns to minimize radioactivity leakage and more effectively use the regenerants. The volume put through a column is reported in terms of column volume, defined as the volume occupied by the resin including the void spaces. Relatively small resin particles (30 x 50 mesh) were used in the $6 \mathrm{~mm}$ diameter column to avoid wall effects. All experiments were conducted at room temperature, which varied between 23 and $30{ }^{\circ} \mathrm{C}$. Strongly acidic and strongly basic ion exchange resins were used in the experiments because of their greater effectiveness for removing radioactivity from wastewaters.

Condensate waste for the study was obtained from the B Plant Fission Products Processing Building. This process condensate arises from the evaporation of waste streams generated by processes for the recovery of fission product ${ }^{137} \mathrm{Cs},{ }^{90} \mathrm{Sr}$ and selected rare earths. The evaporated waste contains ammonium salts in an alkaline solution which results in ammonia volatilization and subsequent absorption in the condensate. Chemical and radiochemical analyses of BCP samples taken in August and September of 1969 are reported in Table 1.

A steam stripper was fabricated for use in removing ammonia from the BCP. The stripping column consisted of 0.5 in. ceramic Intalox $($ saddles packed in a 2 in. ID glass pipe to a depth of 3 feet. The stripper was operated at a feed rate of $21 \mathrm{ml} / \mathrm{min}$

(R) Trademark of the Norton Company 
TABLE 1. Chemical and Radiochemical

Analyses of BCP Samples

\begin{tabular}{|c|c|c|}
\hline Analys is & 8/27/69 Samp1e & $9 / 15 / 69$ Sample \\
\hline Ammonia, $\mathrm{mg} / \ell \mathrm{NH}_{4}$ & 3700 & 2700 \\
\hline Sodium, $\mathrm{mg} / \mathrm{l}$ & $<2$ & $<2$ \\
\hline Carbon, Organic, mg/l & 115 & 45 \\
\hline Carbon, Inorganic, mg/l & 795 & 55 \\
\hline Conductivity, $\mathrm{m}$ mohs/cm & 7620 & 2400 \\
\hline Turbidity, JTU & 0.10 & 0.17 \\
\hline $\mathrm{pH}$ & 9.6 & 10.2 \\
\hline Tota1 Beta@0.3 MeV, $\mu \mathrm{Ci} / \mathrm{m} \ell$ & $4.9 \times 10^{-3}$ & $1.1 \times 10^{-3}$ \\
\hline Total Sr e ${ }^{90} \mathrm{Sr}, \mu \mathrm{Ci} / \mathrm{m} \ell$ & $1.5 \times 10^{-5}$ & $5.0 \times 10^{-5}$ \\
\hline${ }^{90} \mathrm{Sr}, \mu \mathrm{Ci} / \mathrm{m} \ell$ & $1.1 \times 10^{-5}$ & $1.7 \times 10^{-5}$ \\
\hline${ }^{144} \mathrm{Ce}-{ }^{144} \operatorname{Pr}, \mu \mathrm{Ci} / \mathrm{m} \ell$ & $2.9 \times 10^{-4}$ & $4.6 \times 10^{-4}$ \\
\hline${ }^{106} \mathrm{Ru}, \mu \mathrm{Ci} / \mathrm{m} \ell$ & $6.6 \times 10^{-5}$ & $3.3 \times 10^{-5}$ \\
\hline${ }^{137} \mathrm{Cs}, \mu \mathrm{Ci} / \mathrm{ml}$ & $1.9 \times 10^{-3}$ & $3.9 \times 10^{-4}$ \\
\hline${ }^{134} \mathrm{Cs}, \mu \mathrm{Ci} / \mathrm{m} \ell$ & $5.2 \times 10^{-5}$ & $6.2 \times 10^{-6}$ \\
\hline $95_{\mathrm{Zr},}, \mu \mathrm{Ci} / \mathrm{m} \ell$ & $2.0 \times 10^{-4}$ & $8.1 \times 10^{-6}$ \\
\hline $95_{\mathrm{Nb}}, \mu \mathrm{Ci} / \mathrm{ml}$ & $1.0 \times 10^{-4}$ & $3.3 \times 10^{-5}$ \\
\hline \multicolumn{3}{|c|}{$\begin{array}{l}\text { with a } 13 \% \text { boil-off rate which removed an average } 96.6 \text { of the } \\
\text { ammonia from the condensate. The stripper was also effective } \\
\text { in removing botli organic carbon and inorganic carbon }\left(\mathrm{CO}_{2}\right) \\
\text { from the BCP as illustrated in Taide } 2 \text {. }\end{array}$} \\
\hline
\end{tabular}


TABLE 2. Removal of Ammonia, Organic Carbon, and Inorganic Carbon by steam stripping

$\frac{\text { Analysis }}{\mathrm{NH}_{3}}$

Organic Carbon

Inorganic Carbon

$\mathrm{pH}$

\begin{tabular}{|c|c|}
\hline $\begin{array}{l}\text { Feed, } \\
\mathrm{mg} / \mathrm{l}\end{array}$ & $\begin{array}{c}\text { Effluent, } \\
\text { mg/e }\end{array}$ \\
\hline 3700 & 15 \\
\hline 115 & - \\
\hline 795 & 10 \\
\hline
\end{tabular}

\begin{tabular}{|c|c|}
\hline $9 / 15$ & 9 Sample \\
\hline $\begin{array}{l}\text { Feed, } \\
\mathrm{mg} / \mathrm{l}\end{array}$ & $\begin{array}{c}\text { Effluent, } \\
\text { mg/e }\end{array}$ \\
\hline 2700 & 13 \\
\hline 45 & 13 \\
\hline 55 & 4.5 \\
\hline 10.2 & 9.0 \\
\hline
\end{tabular}

DISCUSSION

Initial laboratory studies were conducted with BCP samples and a strong acid cation exchange resin column in series with a strong base anion exchange resin column to determine the decontamination factors (DF) obtainable under a variety of conditions. Both steam stripped and non-steamstripped BCP was employed with the cation exchange resin in either the $\mathrm{H}^{+}$form or the $\mathrm{NH}_{4}^{+}$form. The anion exchange resin was used in the $\mathrm{OH}^{-}$ form only. Two liters of BCP feed were pumped through both the cation column and anion column in series before a 1 liter sample of effluent was removed first from the cation column and then from the anion column. Another liter was pumped through both columns and the effluent sampling repeated. The radionuclide concentrations in the influent and effluent samples are listed in Tables $3,4,5$ and 6 along with decontamination factors.

The largest decontamination factors are shown in Tables 3 and 4 , where a $\mathrm{H}^{+}$from cation resin column was used in series with an $\mathrm{OH}^{-}$form anion resin column with steam stripped BCP. The results are in agreement with ion exchange studies conducted with other wastewasters where $\mathrm{H}^{+}$form cation exchange resins 
TABLE 3. Radionuclide Concentrations and Decontamination Factors for an $\mathrm{H}^{+}$Based Cation Resin in Series with an $\mathrm{OH}^{-}$Based Anion Resin Column with Steam Stripped BCP Sampled on $8 / 27 / 69$

$\frac{\text { Stream }}{\text { Influent }}$

Column Column
Volumes

Influent

Cation Effluent

$$
\begin{aligned}
& \text { Tota1 Beta } \\
& \begin{array}{l}
\text { Conc. } \\
\mu \mathrm{Ci} i / \mathrm{ml} \quad \mathrm{DF}
\end{array}
\end{aligned}
$$$$
3300
$$

$$
83
$$$$
24
$$$$
1.5 \quad 2200
$$$$
25
$$

$$
5.6
$$

139

590

Cation Effluent

Anion Effluent

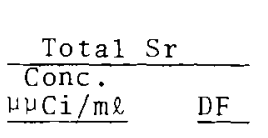

$$
5.6
$$

$$
0.012
$$

$$
0.018
$$

0.028

$0.051 \quad 110$

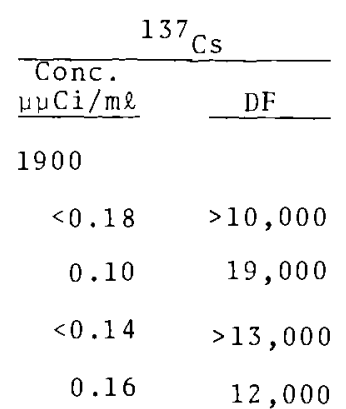

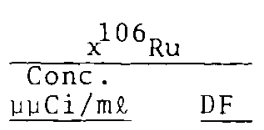

$$
36
$$

$$
\frac{144 \mathrm{Ce}^{144} \mathrm{Pr}}{\mathrm{Conc} \cdot \mathrm{Ci} / \mathrm{m \ell} \quad \mathrm{DF}}
$$

$<2$

Resin Column Dimensions . . 1.9 in. diam, 12.7 in. high

Resin Column Volume... . $36 \mathrm{~cm}^{3}$

Flow Rate......... 30 column volumes/hr

Ammonia Concentration ... . $15 \mathrm{mg} / \mathrm{e} \mathrm{NH}_{3}$

Cation Resin. . . . . . Dowex $50, \mathrm{H}^{+}$form

Anion Resin ....... Dowex $1, \mathrm{OH}^{-}$form 
TABLE 4. Radionuclide Concentrations and Decontamination Factors in Series for an $\mathrm{H}^{+}$Based Cation Resin and an $\mathrm{OH}^{-}$Based Anion Resin Column with Steam Stripped BCP Sampled on 9/15/69

\begin{tabular}{|c|c|c|c|c|c|c|c|c|c|c|c|c|}
\hline & \multirow[b]{2}{*}{ Stream } & \multirow[b]{2}{*}{$\begin{array}{l}\text { Column } \\
\text { Volumes }\end{array}$} & \multicolumn{2}{|c|}{ Total Beta } & \multicolumn{2}{|c|}{ Tota $1 \mathrm{Sr}$} & \multicolumn{2}{|c|}{${ }^{137} \mathrm{Cs}$} & \multicolumn{2}{|c|}{${ }^{106} \mathrm{Ru}$} & \multicolumn{2}{|c|}{${ }^{144} \mathrm{Ce}-{ }^{144} \mathrm{Pr}$} \\
\hline & & & $\begin{array}{l}\text { Conc. } \\
\mu \mu \mathrm{C} i / \mathrm{m} \ell\end{array}$ & $\underline{D F}$ & $\begin{array}{l}\text { Conc } \\
\mu \mu \mathrm{Ci} / \mathrm{ml}\end{array}$ & $\mathrm{DF}$ & $\begin{array}{l}\text { Conc. } \\
\mu \mu \mathrm{Ci} / \mathrm{ml}\end{array}$ & DF & $\begin{array}{l}\text { Conc. } \\
\mu \mu \mathrm{C} / \mathrm{m} \ell\end{array}$ & $\underline{D F}$ & $\begin{array}{l}\text { Conce } \\
\mu \mu \mathrm{C} / / \mathrm{m} \ell\end{array}$ & $\underline{D F}$ \\
\hline & Influent & & 1000 & & 39 & & 430 & & 27 & & $<15$ & \\
\hline & Cation Effluent & 83 & 53 & 19 & 0.084 & 460 & 0.23 & 1900 & 9.6 & 2.8 & & \\
\hline V & Anion Effluent & 83 & 4.4 & 230 & 0.082 & 480 & 0.16 & 2700 & 0.53 & 52 & & \\
\hline & Cation Effluent & 139 & 43 & 23 & 0.079 & 490 & 0.21 & 2100 & 8.2 & 3.3 & & \\
\hline & Anion Effluent & 139 & 3.2 & 310 & $<0.046$ & $>850$ & 0.15 & 2900 & $<0.6$ & $>42$ & & \\
\hline & $\begin{array}{l}\text { Resin Column Din } \\
\text { Resin Column Vol } \\
\text { Flow Rate. . } \\
\text { Ammonia Concentr } \\
\text { Cation Resin. } \\
\text { Anion Resin. }\end{array}$ & 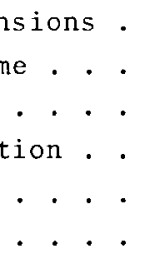 & 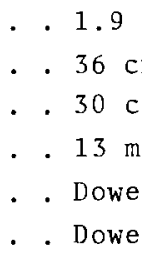 & $\begin{array}{l}\mathrm{diam}, \\
\mathrm{mn} \mathrm{vo} \\
\mathrm{NH}_{3} \\
0, \mathrm{H}^{+} \\
\mathrm{OH}^{-}\end{array}$ & $\begin{array}{l}.7 \mathrm{~cm} \mathrm{hig} \\
\mathrm{es} / \mathrm{hr}\end{array}$ & & & & & & & \\
\hline
\end{tabular}


TABLE 5. Radionuclide Concentrations and Decontamination Factors for Effluents from $\mathrm{NH}_{4}$ Based Cation Resin and $\mathrm{OH}^{-}$Based Resin Column in Series with Steam Stripped BCP Sampled on $9 / 15 / 69$

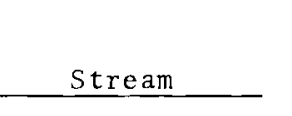

Influent

Cation Effluent

Anion Effluent

Cation Effluent

Anion Effluent

$$
\text { Column }
$$

Volumes

83

\section{3}

83

139

139

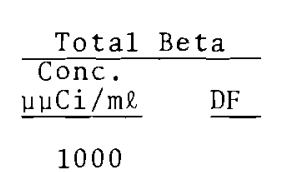

1000

$290 \quad 3.3$

$98 \quad 10$

$300 \quad 3.3$

$210 \quad 4.8$

.8

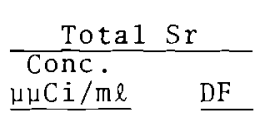

39

0.34

0.19

0.24

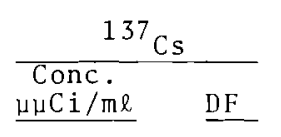

430

1.1390

$0.81 \quad 530$

$1.2 \quad 360$

$1.4 \quad 310$

$\frac{106 \mathrm{Ru}}{\underline{\mu \mathrm{Conc} i \mathrm{~m} \ell} \quad \underline{\mathrm{DF}}}$

27

$16 \quad 1.7$

$2.1 \quad 13$

20

3.5

$\begin{array}{cc}\frac{144}{{ }^{14} \mathrm{Ce}-{ }^{144} \mathrm{Pr}} \\ \begin{array}{cc}\mu \mu \mathrm{Ci} / \mathrm{m} \ell \\ 240\end{array} & \underline{\mathrm{DF}} \\ 170 & 1.4 \\ 66 & 3.6 \\ 180 & 1.3 \\ 150 & 1.6\end{array}$

Resin Column Dimensions . . . $1.9 \mathrm{~cm} \mathrm{diam,} 12.7 \mathrm{~cm} \mathrm{high}$

Resin Column Volume... $36 \mathrm{~cm}^{3}$

Ammonia Concentration .. . . $13 \mathrm{mg} / \ell \mathrm{NH}_{3}$

Cation Resin... . . . . Dowex $50, \mathrm{NH}_{4}^{+}$form

Anion Resin... .... Dowex $1, \mathrm{OH}^{-}$form

flow Rate........ 30 columr volumes/hr 
TABLE 6. Radionuclide Concentrations and Decontamination Factors for Effluents from $\mathrm{NH}_{4}^{+}$Based Cation Resin and $\mathrm{OH}^{-}$Based Anion Resin Columns in Series with Untreated BCP Sampled on $9 / 15 / 70$

\begin{tabular}{|c|c|c|c|c|c|c|c|}
\hline \multirow[b]{2}{*}{ Stream } & \multirow[b]{2}{*}{$\begin{array}{l}\text { Column } \\
\text { Volumes } \\
\end{array}$} & \multicolumn{2}{|c|}{ Tota1 Beta } & \multicolumn{2}{|c|}{ Tota $1 \mathrm{Sr}$} & \multicolumn{2}{|c|}{${ }^{137} \mathrm{Cs}$} \\
\hline & & $\begin{array}{l}\text { Conc. } \\
\mu \mu \mathrm{C} i / m \ell\end{array}$ & DF & $\begin{array}{l}\text { Conc. } \\
\mu \mu \mathrm{C} i / \mathrm{ml}\end{array}$ & $\underline{\mathrm{DF}}$ & $\begin{array}{l}\text { Conc. } \\
\mu \mu \mathrm{Ci} / \mathrm{m} \ell\end{array}$ & $\underline{\mathrm{DE}}$ \\
\hline Influent & & 1200 & & 38 & & 380 & \\
\hline Cation Effluent & 83 & 390 & 3.1 & 0.57 & 67 & 3.4 & 110 \\
\hline Anion Effluent & 83 & 250 & 4.8 & 0.43 & 88 & 5.0 & 77 \\
\hline Cation Effluent & 139 & 500 & 2.4 & 0.64 & 59 & 50 & 7.7 \\
\hline Anion Effluent & 139 & 790 & 1.4 & 0.64 & 59 & 240 & 1.6 \\
\hline
\end{tabular}

\begin{tabular}{|c|c|c|c|}
\hline \multicolumn{2}{|c|}{${ }^{106} \mathrm{Ru}$} & \multicolumn{2}{|c|}{$144 \mathrm{Ce}-{ }^{144} \mathrm{Pr}$} \\
\hline $\begin{array}{l}\text { Conc. } \\
\mu \mu \mathrm{Ci} / \mathrm{m} \ell\end{array}$ & $\underline{\mathrm{DF}}$ & $\begin{array}{l}\text { Conc. } \\
\mu \mu \mathrm{C} i / \mathrm{m} \ell\end{array}$ & DF \\
\hline 270 & & 220 & \\
\hline 270 & 1 & 240 & 1 \\
\hline 85 & 3.2 & 180 & 1.2 \\
\hline 290 & 1 & 220 & 1 \\
\hline 180 & 1.5 & 210 & 1 \\
\hline
\end{tabular}

Resin Column Dimensions... $1.9 \mathrm{~cm}$ diam, $12.7 \mathrm{~cm}$ high

Resin Column Volume... . $36 \mathrm{~cm}^{3}$

Flow Rate......... 30 column volumes $/ \mathrm{hr}$

Ammonia Concentration . . . $2700 \mathrm{mg} / \mathrm{l} \mathrm{NH}_{3}$

Cation Resin........ Dowex $50, \mathrm{NH}_{4}^{+}$form

Anion Resin....... Dowex 1, $\mathrm{OH}^{-}$form 
performed better tian other ionic forms for the cation excinange resins. (10) The use of the $1^{+}$form of a cation exchange resin lowers the pli of the liquid in the cation column thereoy inducing greater uptake of tire radioactivity. (11) Rare earth fission products, in particular, are poorly removed from neutral to alkaline solutions by ion excllange. The results given in Table 5 reveals the effect of the relatively high ammonia concentration in non-steam stripped BCP on the DFs obtainable by ion exchange.

The decrease of total beta IFs with increasing column volumes is largely the result of ${ }^{137} \mathrm{Cs}$ breaking through the cation exchange resin after 139 column volumes. The use of $\mathrm{H}^{+}$ cation resin with non-steamstripped $B C P$ is impractical due to (1) gassing in the resin column from acidification of carbonates in the BCP and (2) the quick exhaustion of the resin by the high concentration of ammonia present.

The results in Tables 3 and 4 indicated sufficient uptake of radioactivity from steam stripped BCP by cation and anion exchange with $\mathrm{H}^{+}$and $\mathrm{OH}^{-}$, respectively, to warrant further investigation with long term column runs. The results of the first extended run are illustrated in Figure 1. The initial total beta and ${ }^{137} \mathrm{Cs}$ DFs exceeded $10^{3}$ and breakthrough above discharge limits occurred at 1800 column volumes. Strontium removal continued well past the ${ }^{137} \mathrm{Cs}$ breakthrough. On the basis of the $\mathrm{NH}_{4}^{+}$concentration, cesium breakthrough should not have occurred prior to 5000 column volumes. Further analysis of the steam stripped BCP used in the first extended runs disclosed a hardness value of $49 \mathrm{mg} / 1$ iter or $\mathrm{CaCO}_{3}$ or $1 \times 10^{-3}$ equivalents per liter. At an approximate ion exchange capacity of 2 equivalents per 1 iter of resin, hardness breakthrough near 2000 column volumes is expected. Cesium breakthrough occurs just ahead of hardness breakthrough with sulfonated polystyrenedivinylbenzene cation exchange resins. It may be noted in 
Figure 1 that the ${ }^{137} \mathrm{Cs}$ and total beta breakthrough exceeds $100 \%$ from about 2000 to 3000 column volumes throughput. This results from sorption of the ${ }^{137} \mathrm{Cs}$ in a band preceding that of $\mathrm{Ca}^{+2}$ and $\mathrm{Mg}^{+2}$ followed by elution of the ${ }^{137} \mathrm{Cs}$ by the spreading band of sorbed $\mathrm{Ca}^{+2}$ and $\mathrm{Mg}^{+2}$. The presence of hardness ions in the $\mathrm{BCP}$ results from the addition of a small amount of raw water into this condensate waste stream.

Further extended column runs were conducted to determine the DFs and breakthrough after regeneration of the resin columns. A column of activated carbon, in series after the anion column, was included for ${ }^{106} \mathrm{Ru}$ and ${ }^{60}$ Co removal, if present in the BCP. The resin and carbon columns were regenerated in accordance with the water recycle process proposed by the Oak Ridge National Laboratory (12) ( 6 column volumes of $4 \mathrm{M} \mathrm{HNO}_{3}$ to regenerate the cation column, 8 column volumes of $2 \mathrm{M} \mathrm{NaOH}$ to regenerate the anion column, and 4 column volumes of $0.5 \mathrm{M} \mathrm{HNO}_{3}$ to regenerate the the carbon column). Figures 2, 4, and 6 illustrate the influent and cation effluent concentration for the three runs. Figures 3 , 5 , and 7 illustrate the influent and effluent concentrations for the cation and anion columns in series. The second run was terminated after 4100 column volumes because of gassing in the cation exchange bed. The gassing is believed to have been caused by high room temperatures during a period of warm weather (feed became supersaturated with air).

Cesium and strontium exist predominantly as cations and are removed to a large extent on the cation exchange column. Cesium breakthrough from the cation column began at 3000 column volumes (Figures 2 and 6 ) and reached $50 \%$ breakthrough at 6000 column volumes. The hardness value of the wastewater in these runs was $11 \mathrm{mg} / 1$ ter as $\mathrm{CaCO}_{3}$ or about $20 \%$ of that in Figure 1 . No strontium breakthrough occurred in the water recycle runs illustrated in Figures 2 through 7; however, strontium DFs varied between 5 and 20 , which is considerably less than earlier runs. It is believed that the lower cationic concentrations of 
steam stripped $B C P$ used in the vater recycle runs prevented the cation exchange resin from lowering the pH. This resulted in a loss of efficiency and less uptake of strontium. Due to a lack of buffer in the samples, pH measurements taken several weeks after the experiments were conducted are not considered reliable. To assure slightly acidic conditions in the cation exchange columns, injection of acid into the feed to the column is considered necessary at times to maintain adequate DFs for strontium and rare earths.

Ruthenium appears to be present in both cationic and anionic forms whereas antimony is present only in the anionic form. Breakthrough of the ruthenium and antimony occurred simultaneously from the anion column except for the final run illustrated in Figure 7 , where no uptake of antimony occurred. The cause for no antimony sorption in the final run is unknown. The reported antimony DFs by anion and cation exchange with ORNL low level wastes (12) is 100 as compared to $0-25$ for this study. The character of the ORNL waste is significantly different than that of steam stripped BCP, since the former contains considerably more dissolved electrolytes. Hardness breakthrough occurred at 700 column volumes with the ORNL waste, which would signify some advantage due to a lower $\mathrm{pH}$ in the cation column than would be obtained with BCP.

Cesium and strontium elution curves using $4 \underline{M} \mathrm{HNO}_{3}$ are illustrated in Figure 8 for the cation exchange column. Ruthenium and antimony elution curves using $2.1 \mathrm{NaOH}$ are illustrated in Figure 9 for the anion exchange column. The activated carbon column was regenerated with $0.5 \mathrm{M} \mathrm{HNO}_{3}$ and very 1 ittle ${ }^{60} \mathrm{Co}$ was detected $\left(1 \times 10^{-5} \mu \mathrm{Ci} / \mathrm{ml}\right)$. Ruthenium-106 was also detected in the carion column regenerant but at a level of only 25 times the influent which also indicates low adsorption. No significant sorption was noted across the carbon column during the loading cycles. Cobalt-60 was not detectajle by a gamma scan of the feed. 
The elution curves in Figure 8 show that strontium and cesium elution was complete with 6 column volumes of $4 \mathrm{M}^{\mathrm{HNO}}{ }_{3}$. The elution was about $90 \%$ complete at 3 column volumes. The final 3 column volumes of regenerant with its low concentrations of cesium and strontium are saved for use as the initial regenerant in the next cycle to minimize the amount of acid used. This split regenerant method is also used with the $2 \mathrm{M} \mathrm{NaOH}$ anion regenerant. The low $\mathrm{C} / \mathrm{C}_{0}$ values shown in Figure 9 for ruthenium and antimony result from early breakthrough relative to cesium and stontium. Further, a portion of the ruthenium and trace antimony was desorbed as the band of sorbed macro anion proceeded down the anion exchange column.

\section{TREATMENT PROCESS}

A flow diagram for the combined steam stripping-ion exchange treatment process recommended for decontaminating $B C P$ is given in Figure 10. A possible option not included in the flow diagram is a vacuum deaerator to remove $\mathrm{CO}_{2}$ from the cation column effluent. Removal of the $\mathrm{CO}_{2}$ will increase the length of the service cycle of the anion column which would be particularly important if a significant amount of nitric acid is necessary to maintain a low $\mathrm{pH}$ in the cation column. The anion column is twice as large as the cation column to account for the lower exchange capacity of the anion exchange resin. Both columns can be regenerated at the same time to minimize downtime.

A multimedia sand filter is included as a precautionary measure. Some particulate and colored impurities, which may have come from the waste tanks were noted in the laboratory studies and should be removed prior to ion exchange. The multimedia 
filter is composed of granular anthracite coal, silica sand, and garnet sand graded coarse to fine for in-depth filtration. Recommended filter flow rates are 5 to $7.5 \mathrm{gpm} / \mathrm{ft}^{2}$ and a backwash rate of $15 \mathrm{gpm} / \mathrm{ft}^{2}$ with cool water. Backwash with warm water will require higher flow rates.

Macroreticular ion exchange resins (such as Amberlite IR-200) recommended for use due to the greater fouling resistance and durability of this type of resin. The optimum pH range for the feed to the cation exchange column will be 3.5 to 6 . The ratio of $60 \%$ nitric acid to steam stripped BCP feed will vary from 0 to $10^{-3}$. 
BNWL -1544

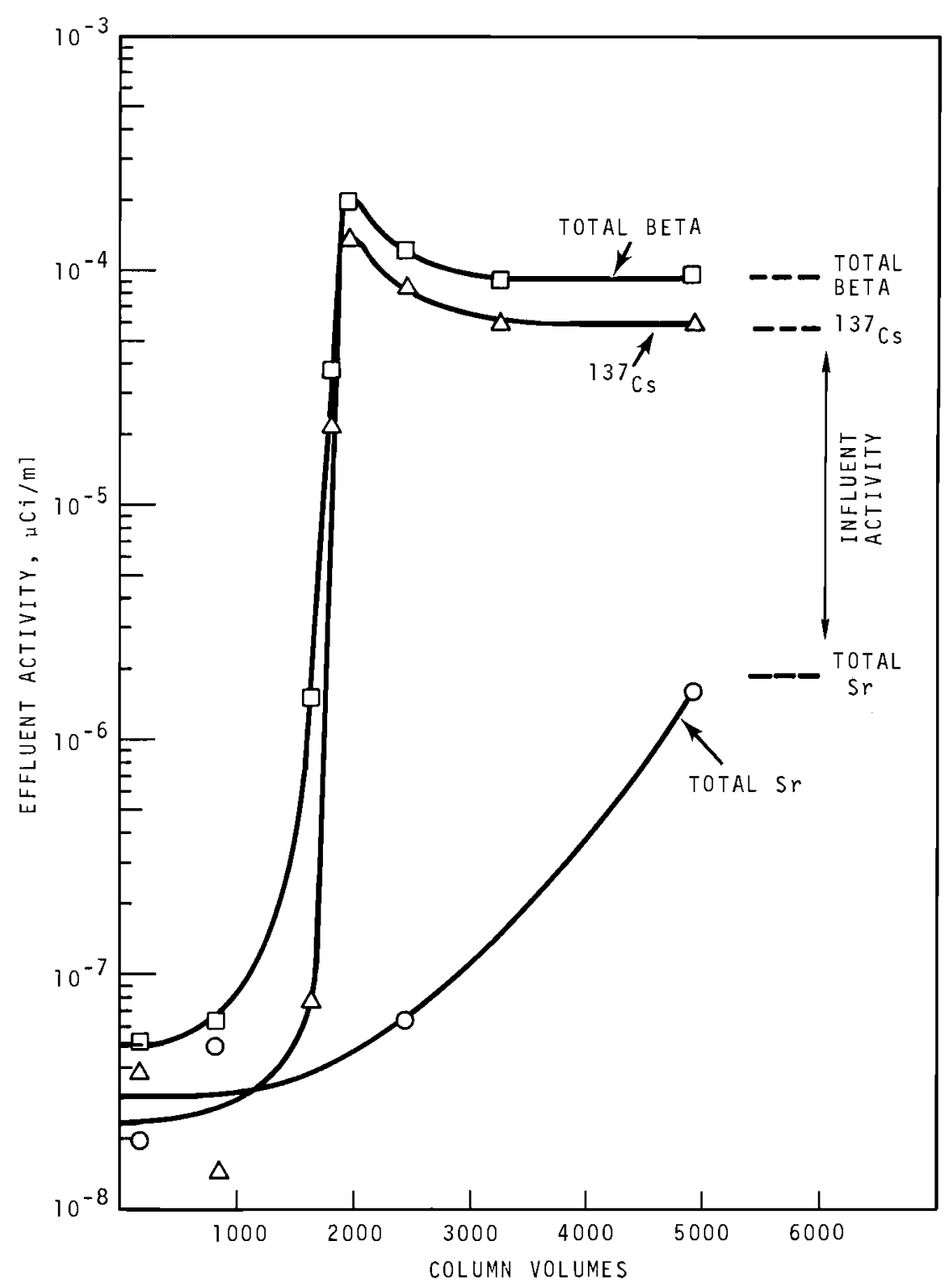

FIGURE 1. Breakthrough Curves for the Principal Radionuclides in Steam Stripped BCP Put Through Cation and Anion Exchange Columns

Resin Column Dimensions . . $6 \mathrm{~mm}$ diam, $21 \mathrm{~cm} \mathrm{high}$ Resin Column Volume. . . $6 \mathrm{~cm}^{3}$

Flow Rate... . . . . . 30 column volumes/hr Ammonia Concentration . . . $1 \mathrm{mg} / \mathrm{l}$

Cation Exchange Resin:. . Amberlite IR200, $\mathrm{H}^{+}$form Anion Exchange Resin. . . Dowex 1 x $8, \mathrm{OH}^{-}$form 
BNWL - 1544

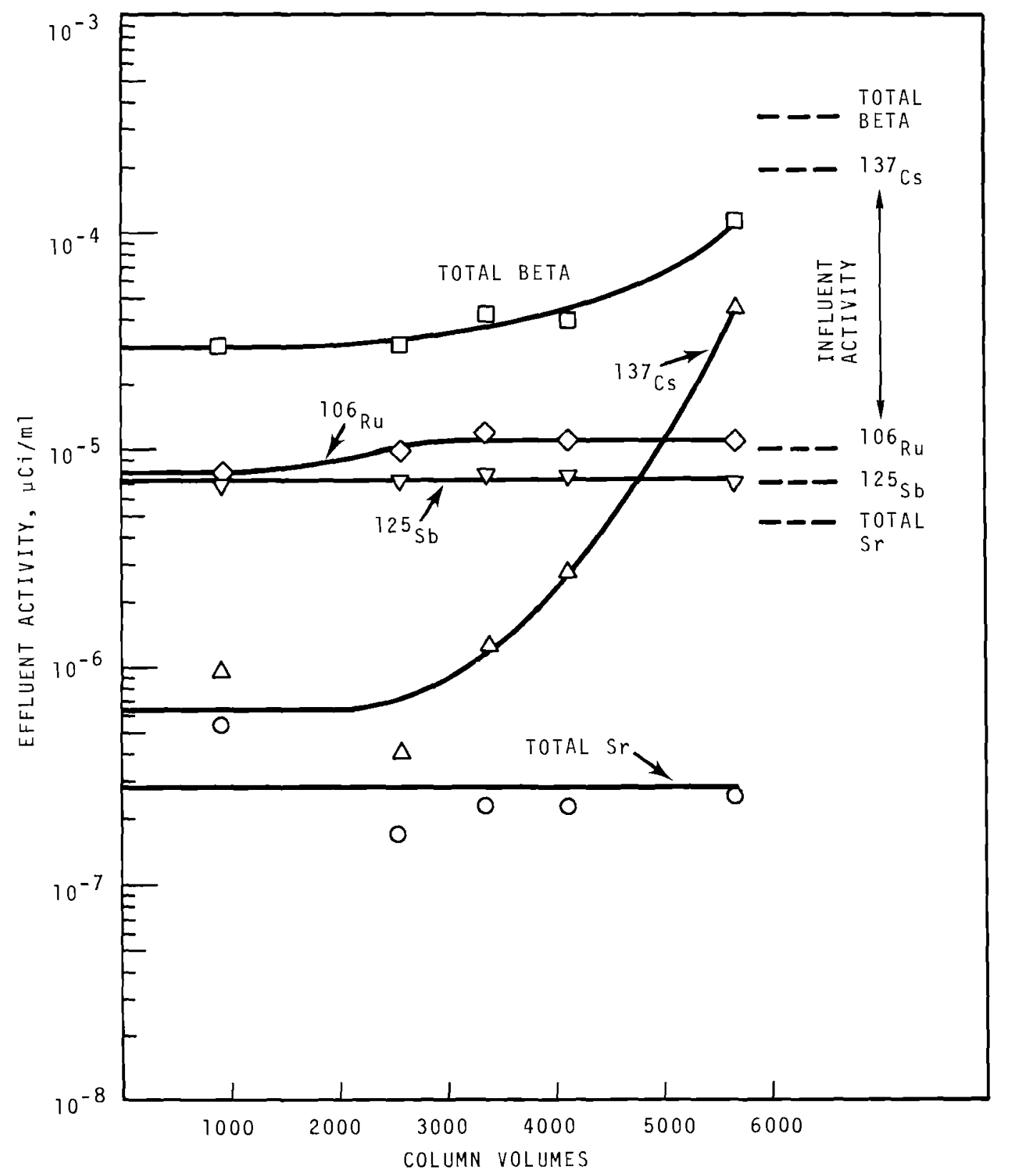

FIGURE 2. Breakthrough Curves for the Principal Radionuclides in steam Stripped BCP Put Through a Cation Exchange Column in Water Recycle Run 1

Resin Column Dimensions . . $6 \mathrm{~mm}$ diam, $21 \mathrm{~cm} \mathrm{high}$ Resin Column Volume... . $6 \mathrm{~cm}^{3}$

Flow Rate.. . . . . . 30 column volumes/hr Ammonia Concentration . . . $3 \mathrm{mg} / \mathrm{liter}$

Cation Exchange Resin.. - Dowex $50 \times 8, \mathrm{H}^{+}$form Anion Exchange Resin. . . Dowex $1 \times 8, \mathrm{OH}^{-}$form 
BNWL -1544

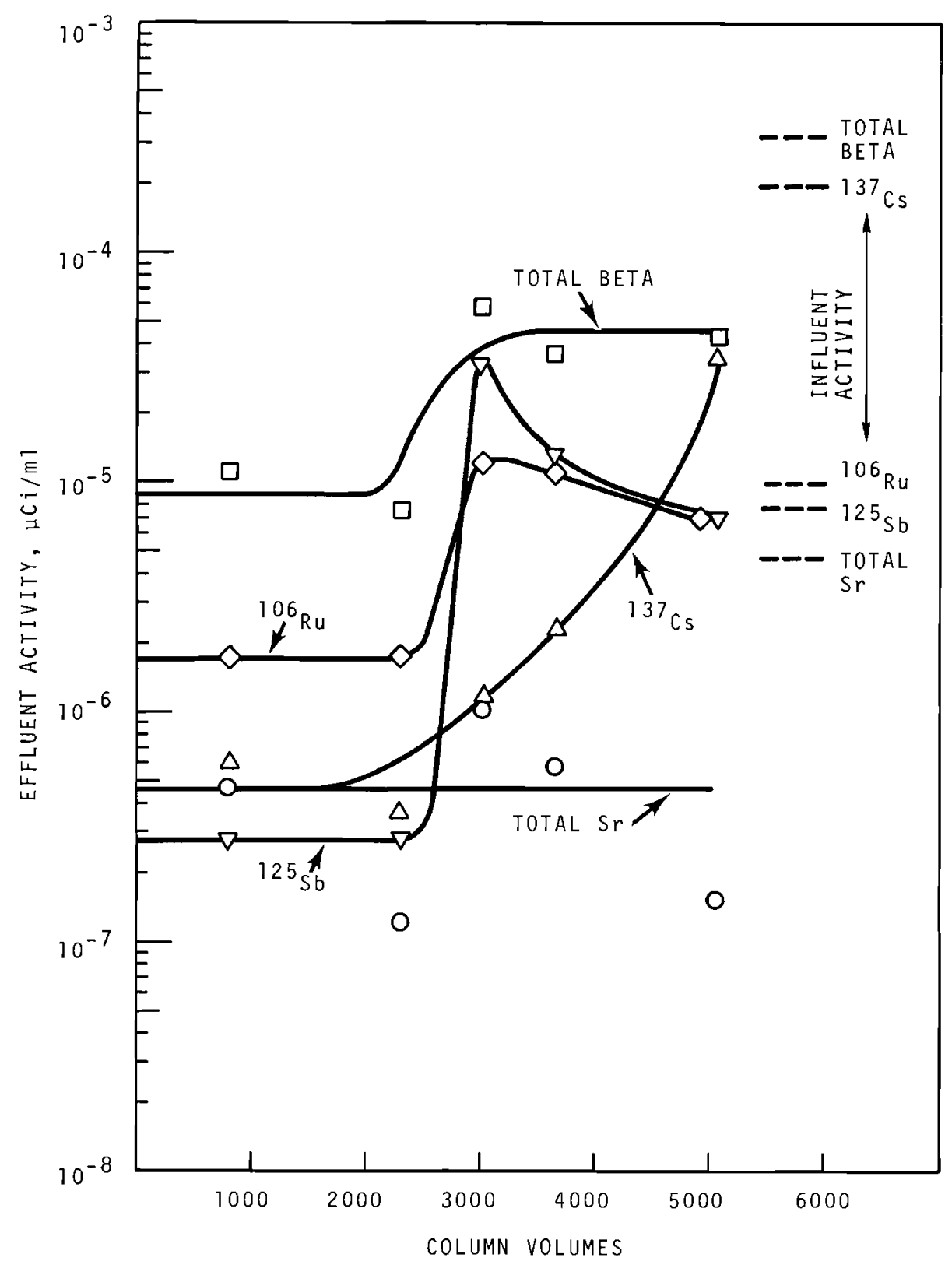

FIGURE 3. Breakthrough Curves for the Principal Radionuclides in Steam Stripped BCP Put Through Cation and Anion Exchange Columns in Water Recycle Run 1

Resin Column Dimensions . . $6 \mathrm{~mm}$ diam, $21 \mathrm{~cm}$ high Resin Column Volume... . $6 \mathrm{~cm}^{3}$ Flow Rate... . . . . 30 column volumes/hr Ammonia Concentration . . . $3 \mathrm{mg} / \mathrm{liter}$ Cation Exchange Resin: - Dowex $50 \times 8, \mathrm{H}^{+}$form Anion Exchange Resin. . . Dowex 1 x $8, \mathrm{OH}^{-}$form 
BNWL -1544

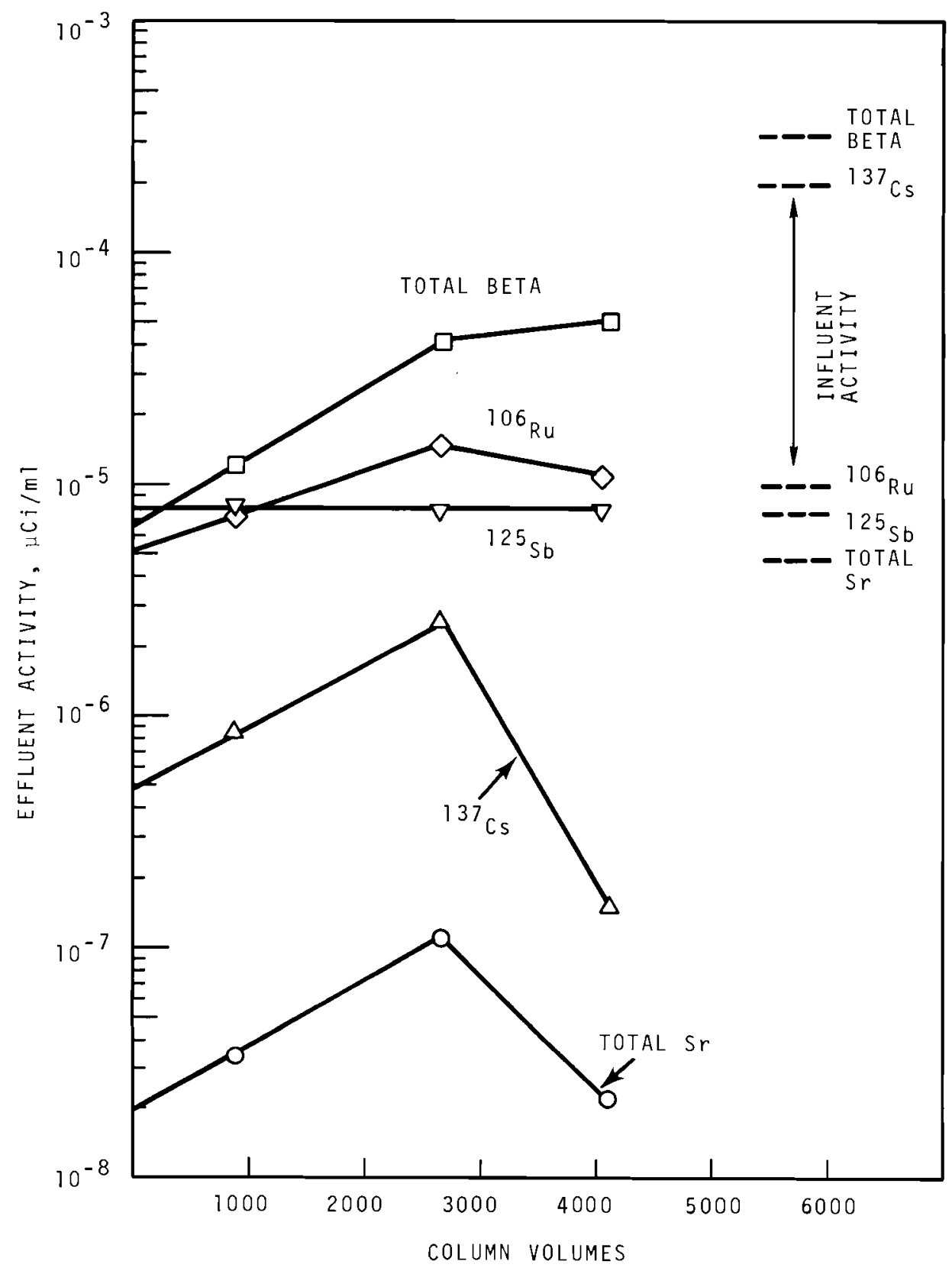

FIGURE 4. Breakthrough Curves for the Principal Radionuclides in Steam Stripped BCP Put Through a Cation Exchange Column in Water Recycle Run 2

Resin Column Dimensions . . $6 \mathrm{~mm}$ diam, $21 \mathrm{~cm}$ high Resin Column Volume... $6 \mathrm{~cm}^{3}$

Flow Rate....... . 30 column volumes/hr

Ammonia Concentration . . . $3 \mathrm{mg} / \mathrm{liter}$

Cation Exchange Resin .. Dowex $50 \times 8, \mathrm{H}_{-}^{+}$form Anion Exchange Resin. . . Dowex $1 \times 8, \mathrm{OH}^{-}$form 


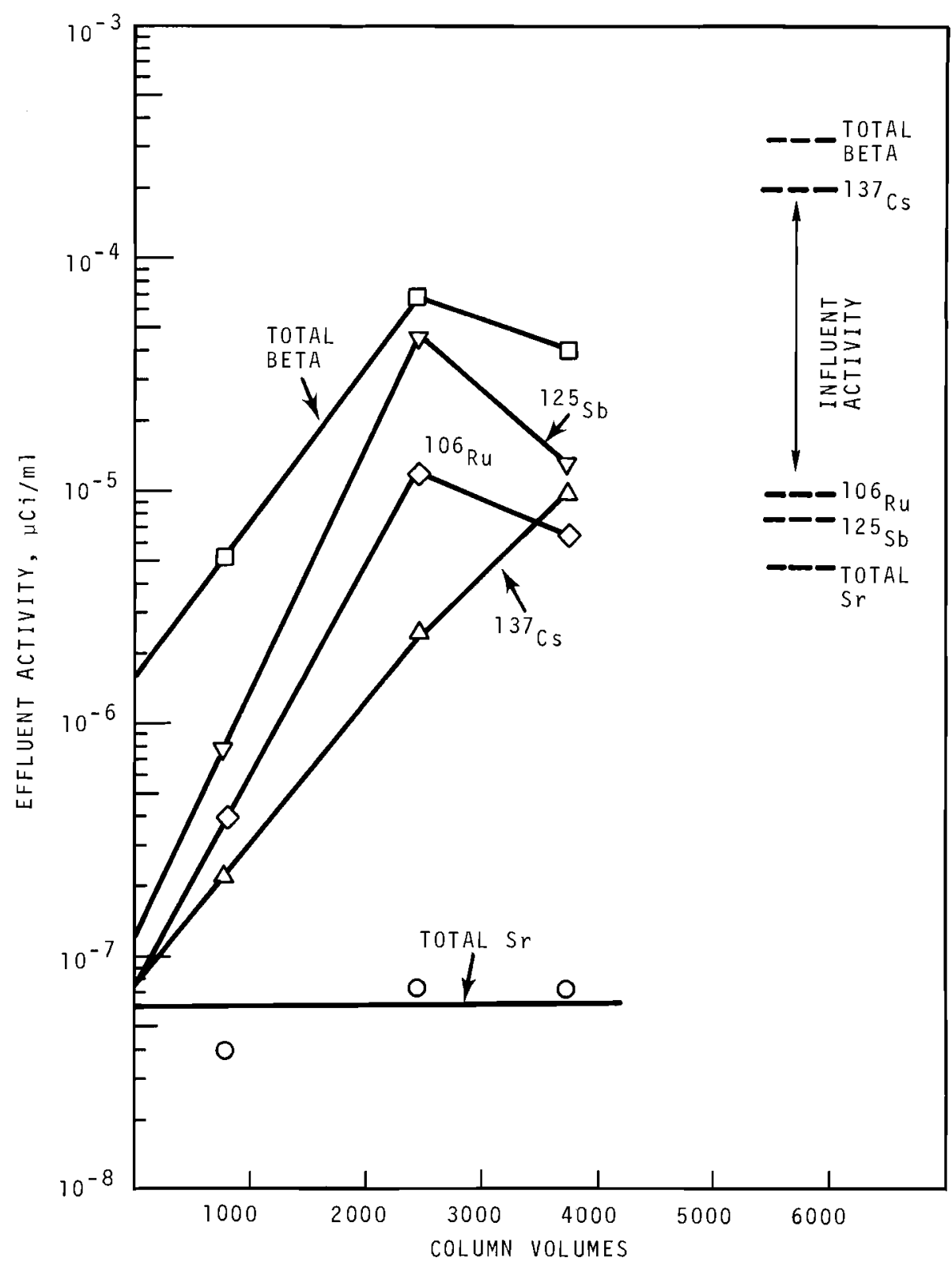

FIGURE 5. Breakthrough Curves for the Principal Radionuclides in Steam Stripped BCP Put Through Cation and Anion Exchange Columns in Water Recycle Run 2

Resin Column Dimensions . . $6 \mathrm{~mm}$ diam, $21 \mathrm{~cm}$ high Resin Column Volume... . $6 \mathrm{~cm}^{3}$

Flow Rate....... . 30 column volumes/hr Ammonia Concentration . . . $3 \mathrm{mg} / \mathrm{liter}$ Cation Exchange Resin.. - Dowex $50 \times 8, \mathrm{H}^{+}$form Anion Exchange Resin. . . . Dowex 1 x $8, \mathrm{OH}^{-}$form 


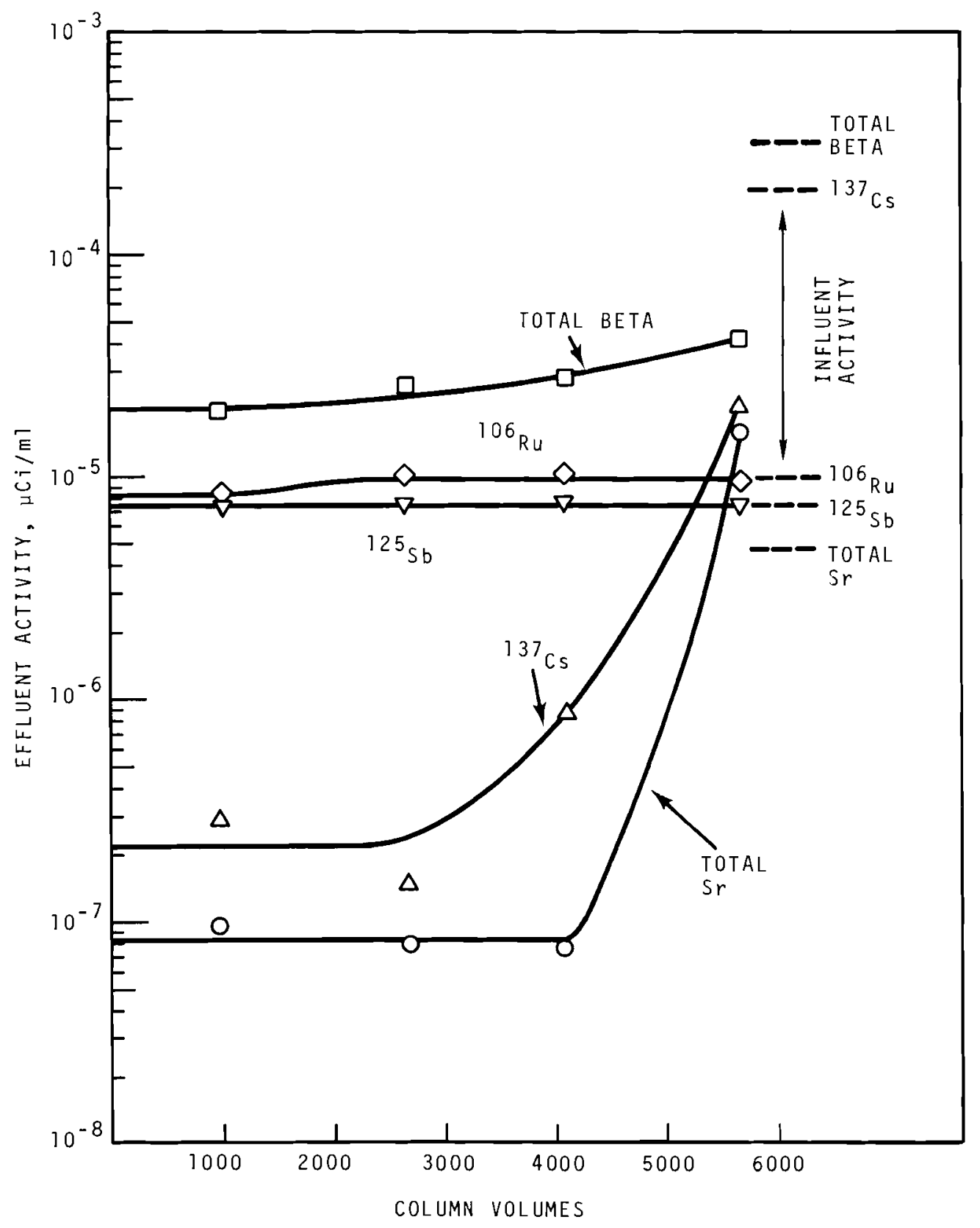

FIGURE 6. Breakthrough Curves for the Principal Radionuclides in Steam Stripped BCP Put Through a Cation Exchange Column in Water Recycle Run 3

Resin Column Dimensions . . $6 \mathrm{~mm}_{3} \mathrm{diam}, 21 \mathrm{~cm}$ high Resin Column Volume... . $6 \mathrm{~cm}^{3}$ Flow Rate... . . . . 30 column volumes/hr Ammonia Concentration . . . $3 \mathrm{mg} /$ liter Cation Exchange Resin .. Dowex $50 \times 8, \mathrm{H}_{-}^{+}$form Anion Exchange Resin. . . Dowex $1 \times 8, \mathrm{OH}^{-}$form 
BNWL -1544

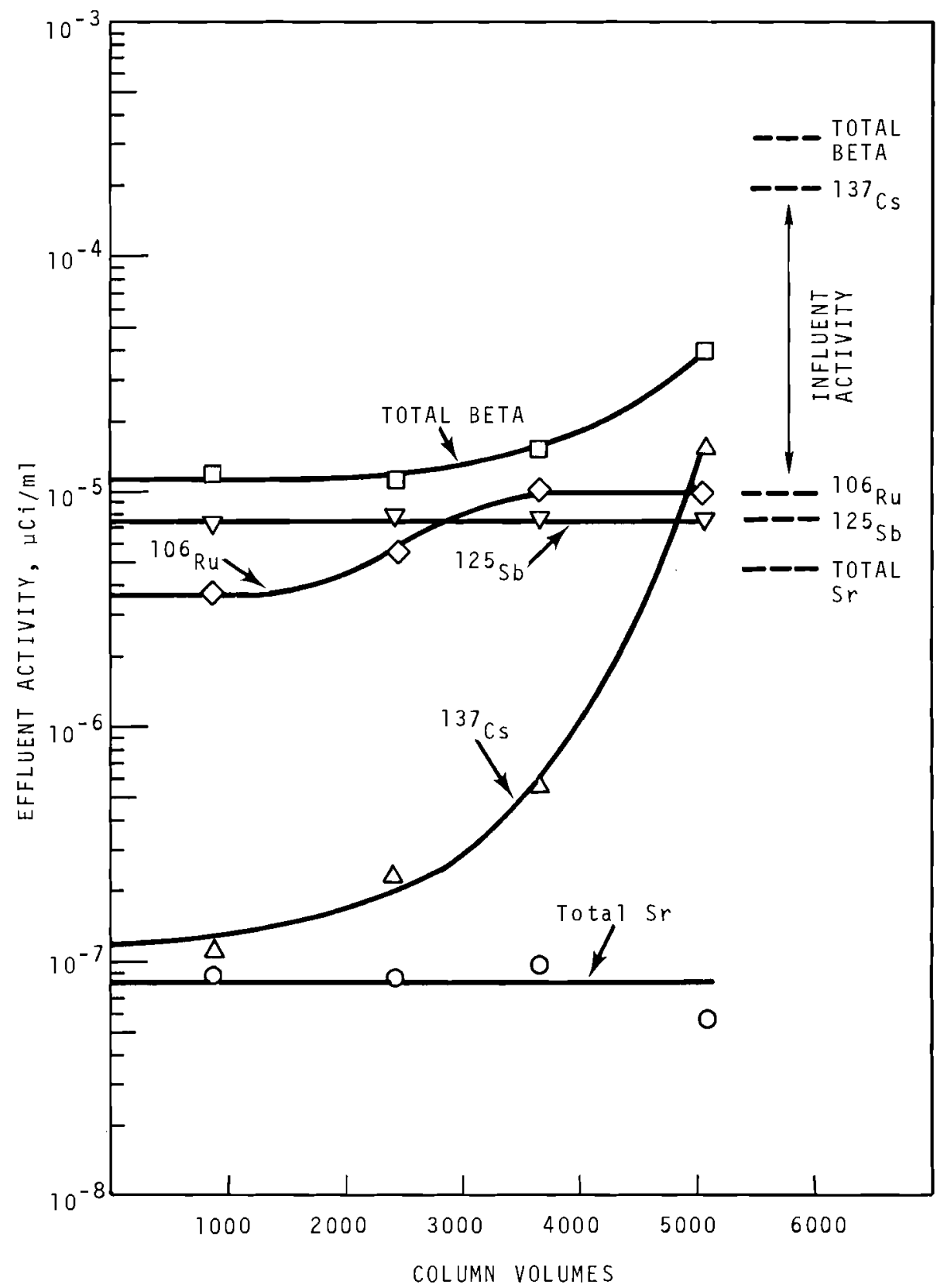

FIGURE 7. Breakthrough Curves for the Principal Radionuclides in Steam Stripped BCP Put Through Cation and Anion Exchange Column in Water Recycle Run 3

Resin Column Dimensions . . $6 \mathrm{~mm}$ diam, $21 \mathrm{~cm}$ high Resin Column Volume... . $6 \mathrm{~cm}^{3}$ Flow Rate... ... . . 30 column volumes/hr Ammonia Concentration . . . $3 \mathrm{mg} / \mathrm{liter}$ Cation Exchange Resin. - Dowex $50 \times 8, \mathrm{H}^{+}$form Anion Exchange Resin. . . Dowex 1 x $8, \mathrm{OH}^{-}$form 


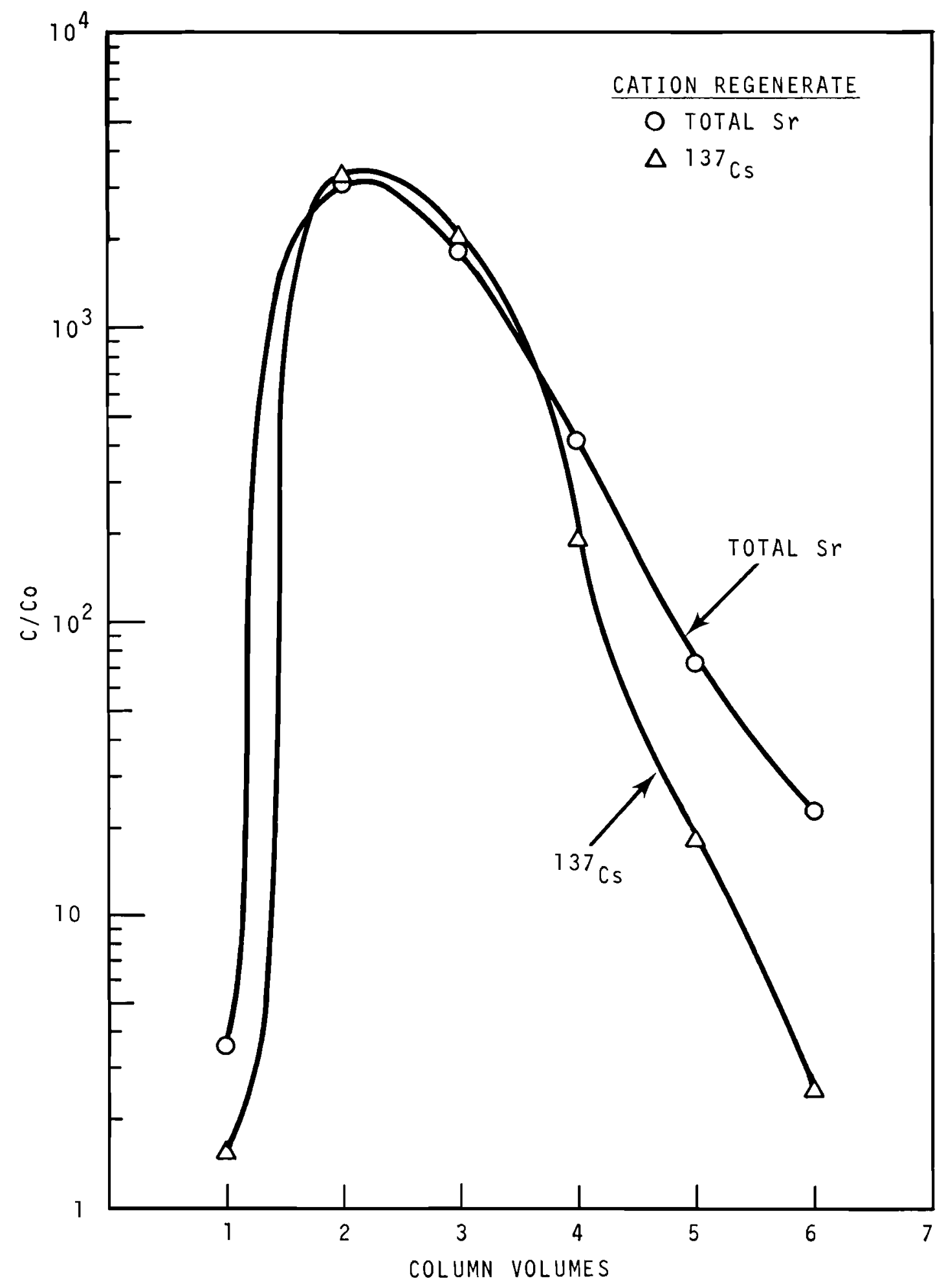

FIGURE 8. Elution Curves for Cesium and Strontium from the Cation Column Using 4M Nitric Acid Upflow 
BNWL - 1544

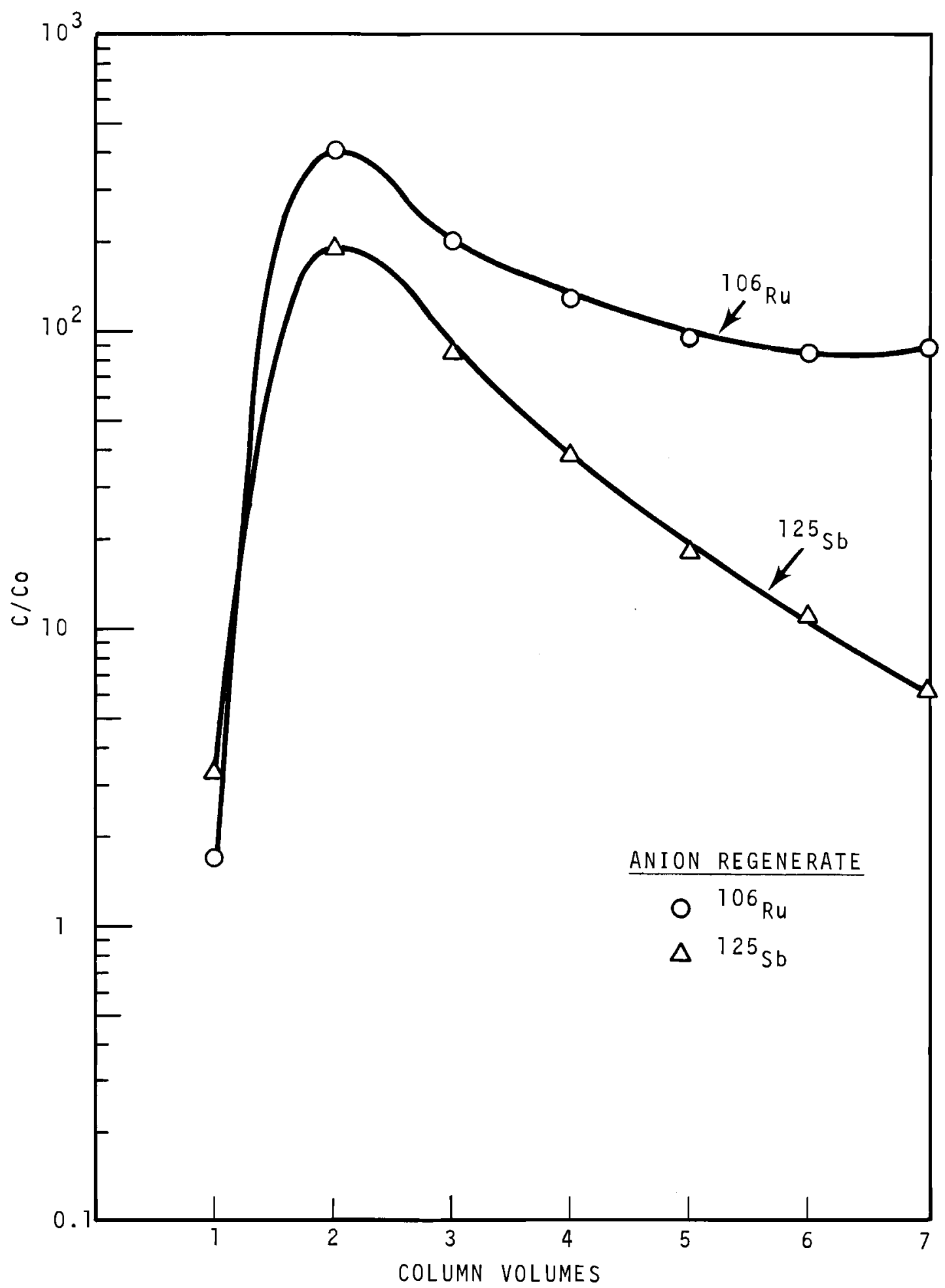

FIGURE 9. Elution Curves for Ruthenium and Antimony from the Anion Column Using 2M Sodium Hydroxide Upflow 


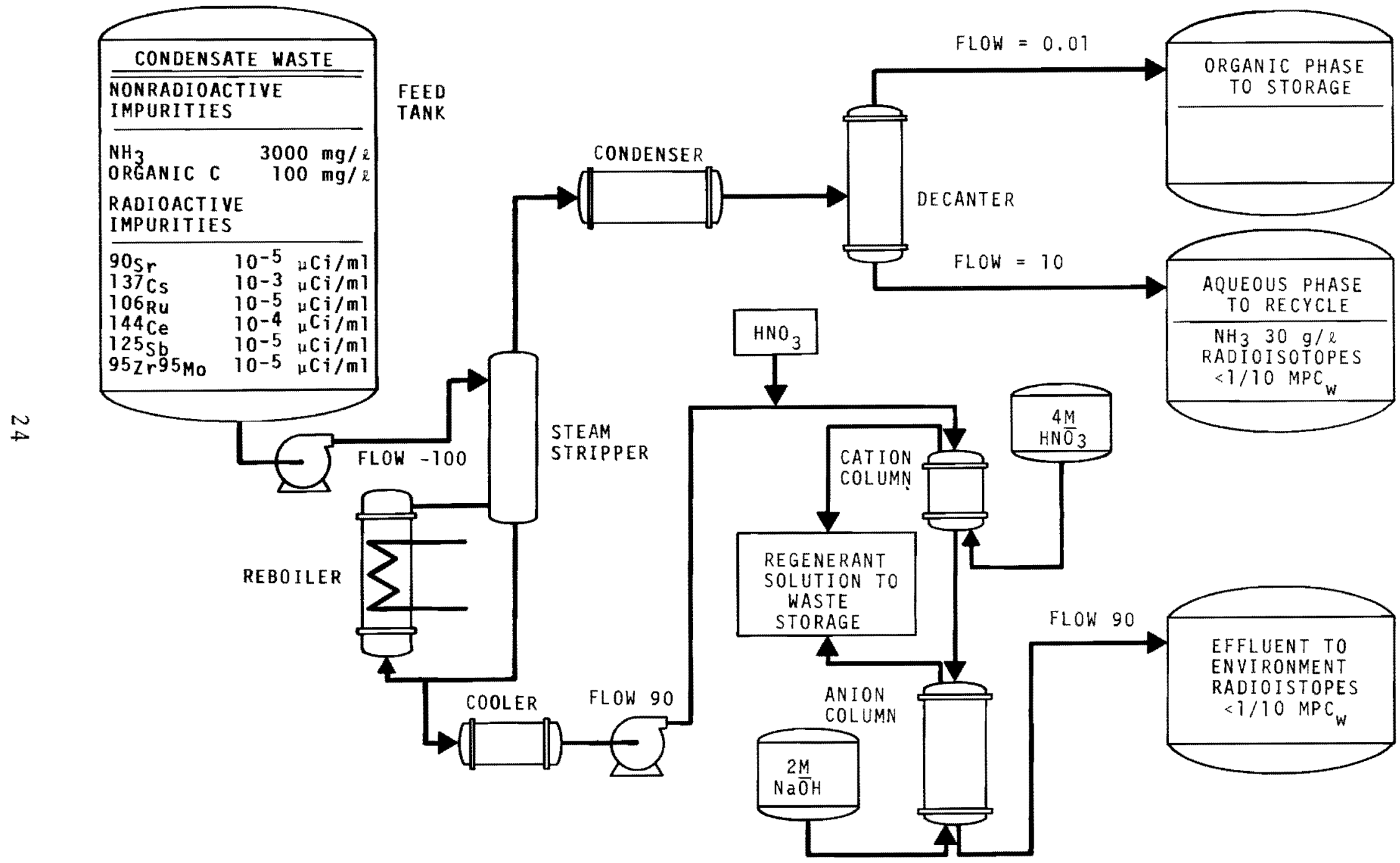

FIGURE 10. Flow Diagram 


\section{REFERENCES}

1. L. A. Emelity. Operation and Control of Ion Exchange Processes for Treatment of Radioactive Wastes, Technical Report Series No. 78. International Atomic Energy Agency, Vienna, 1967.

2. B. W. Mercer. Treatment of Radioactive Wastes by Ion Exchange, BNWL-SA-2369. Paper presented at the 66th National American Institute of Chemical Engineers, Portiand, oregon, August 1969.

3. B. W. Mercer. The Decontamination of Condensates Containing Ammonia, HW-71627. Available from National Technical Information Service, Springfield, Virginia, March 1962.

4. B. W. Mercer. Adsorption of Trace Ions from Intermediate Level Radioactive Wastes by. Ion Exchange, BNWL-180. Battelle-Northwest, Richland, Washington, January 1966.

5. B. W. Mercer, L. L. Ames, R. G. Parkhurst. Removal of $137 \mathrm{Cs}$ from Alkaline Condensate Water, BNWL-8\% Northwest, Richland, Washington, January 1966.

6. B. W. Mercer. Unpublished Data. Battelle-Northwest, Richland, Washington.

7. G. L. Hanson. Personal Communication. Battelze-Northwest, Richland, Washington, March 1970.

8. C. J. Francis. Personal Communications. Atzantic Richfield Hanford Company, Richland, Washington, September 1970.

9. M. W. Wizding and D. W. Rhodes. Removal of Radioisotopes from Solution with Earth Materials from Eastern Idaho, IDO-14624. Idaho Operations Office, Idaho Fal2s, November 1964 .

10. J.M. Skarpelos. Progress in the Treatment of Radioactive Condensate Waste, HW-79174. Available from National Technical Information Service, Springfield, Virginia, october 1963 .

11. H. G. Swope. "Mixed Bed Ion Exchange for the Removal of Radioactivity," J.Am. Water Works Assoc., vol. 49, p. 1085. 1957 .

12. W. C. Yee, F. Delora, and W. E. Shockley. Low-Level Radio-

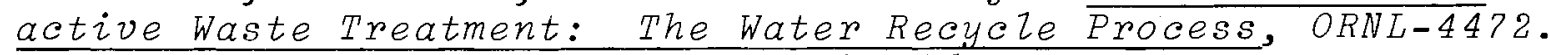
oak Ridge National Laboratory, Oak Ridge, Tennessee, 1970. 
.

.

. 


\section{DISTRIBUTION}

No. of

Copies

OFFS I TE

1

AEC Chicago Patent Group

G. H. Lee

177

AEC Division of Technical Information Extension

ONS ITE - HANFORD

1

AEC Chicago Patent Group

R. K. Sharp (Richland)

3

AEC Richland Operations Office

M. R. Schne11er

O. J. E1gert (2)

Atlantic Richfield Hanford Company

M. D. Alford

S. J. Beard

J. B. Fecht

C. J. Francis

W. L. Godfrey

G. L. Hanson

R. E. Isaacson

G. R. Kiel

C. G. Oberg

L. M. Richards

G. L. Ritter

R. E. Tomlinson

R. E. Van Der Cook

2

RDT Assistant Director for Pacific Northwest Programs

Batte11e-Northwest

L. L. Ames
E. L. Alpen
R. E. Burns
G. L. Culp
J. J. Fuquay
W. A. Haney
B. W. Mercer (30)

D. E. O1esen

R. C. Routson

A. J. Shuckrow

C. J. Touhill

Technical Information Files (5)

Technical Publications (2) 


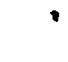

